\title{
Review Article \\ Recent Advances on the Use of Biochemical Extracts as Filaricidal Agents
}

\author{
Nazeh M. Al-Abd, ${ }^{1}$ Zurainee Mohamed Nor, ${ }^{1}$ Abdulelah H. Al-Adhroey, \\ Anwar Suhaimi, ${ }^{2}$ and S. Sivanandam ${ }^{1}$ \\ ${ }^{1}$ Department of Parasitology, Faculty of Medicine, University of Malaya, 50603 Kuala Lumpur, Malaysia \\ ${ }^{2}$ Department of Rehabilitation Medicine, Faculty of Medicine, University of Malaya, 50603 Kuala Lumpur, Malaysia
}

Correspondence should be addressed to Nazeh M. Al-Abd; nazehali78@yahoo.com

Received 12 April 2013; Accepted 5 September 2013

Academic Editor: Yew-Min Tzeng

Copyright (C) 2013 Nazeh M. Al-Abd et al. This is an open access article distributed under the Creative Commons Attribution License, which permits unrestricted use, distribution, and reproduction in any medium, provided the original work is properly cited.

Lymphatic filariasis is a parasitic infection that causes a devastating public health and socioeconomic burden with an estimated infection of over 120 million individuals worldwide. The infection is caused by three closely related nematode parasites, namely, Wuchereria bancrofti, Brugia malayi, and B. timori, which are transmitted to human through mosquitoes of Anopheles, Culex, and Aedes genera. The species have many ecological variants and are diversified in terms of their genetic fingerprint. The rapid spread of the disease and the genetic diversification cause the lymphatic filarial parasites to respond differently to diagnostic and therapeutic interventions. This in turn prompts the current challenge encountered in its management. Furthermore, most of the chemical medications used are characterized by adverse side effects. These complications urgently warrant intense prospecting on bio-chemicals that have potent efficacy against either the filarial worms or thier vector. In lieu of this, we presented a review on recent literature that reported the efficacy of filaricidal biochemicals and those employed as vector control agents. In addition, methods used for biochemical extraction, screening procedures, and structure of the bioactive compounds were also presented.

\section{Introduction}

Lymphatic filariasis is a disease that is caused by parasitic helminthes, namely, Wuchereria bancrofti, Brugia malayi, and B. timori. The parasites are transmitted by several mosquito species $[1,2]$, and the disease is reported to constitute serious public health and socioeconomic issues. In fact, it is said to be a major cause of acute and chronic morbidity in humans within tropical and subtropical areas of Africa, Asia, the Western Pacific, and some parts of the Americas [3]. It has been characterized with long-term infection through suppression of host immunity [1]. The pathogenesis of lymphatic filariasis is linked to host inflammation invoked by the death of the parasite (Figure 1), resulting in an altered lymphatic system and the abnormal enlargement of body for example, hydrocoele, lymphedema, and elephantiasis, causing pain and severe disability. The filarial species that infect people are known to coexist in a mutualistic endo-symbiotic relationship with Wolbachia bacteria, which are reported to be essential for the growth, development, and survival of the nematode hosts [1]. These endosymbionts are said to be among the factors that contribute to the inflammatory effect of this disease [1]. According to World Health Organization (WHO) fact sheets, more than 1.3 billion individuals in 72 countries worldwide are threatened by lymphatic filariasis, with over 120 million individuals being currently infected, and about 40 million being disfigured and incapacitated by the disease [2].

Currently, the chemotherapeutic drugs used to treat filariasis include doxycycline therapy, which targets the endosymbionts, delivers macrofilaricidal activity and improves pathological outcomes. Interestingly, the drug is said to be effective, even when used as monotherapy [1]. Combined therapeutic dosage of diethylcarbamazine (DEC), ivermectin, and 


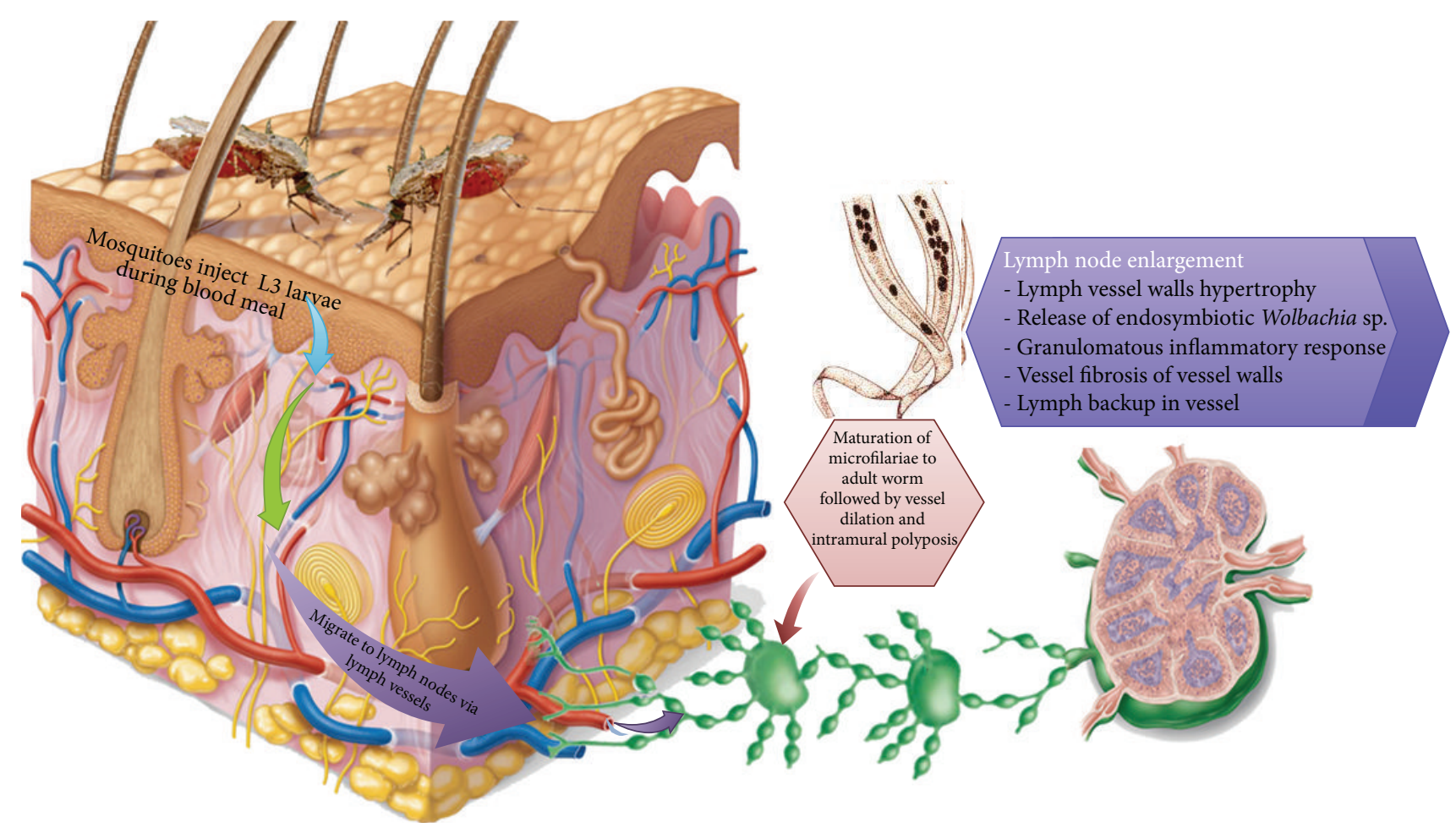

FIGURE 1: Inflammatory response in lymphatic filariasis.

albendazole effectively reduces microfilariae in blood $[1,4]$. Unfortunately, most of these chemical medications are characterized by adverse side effects. For example, DEC has been around and in use since 1947 and is considered a good medication against microfilarial infection. Regrettably, this drug is reported to have a detrimental side effect [4]. Ivermectin, though reported to significantly lower the concentration of the microfilaria in the blood, was found to be associated with recurrence of microfilaraemia after treatment [4]. Hence, considering the public health and socioeconomic burden due to this disease, research on exploration and development of alternative therapeutic drugs, especially placid and/or less hazardous drugs of natural "organic" origin, is highly recommended.

Among the complementary alternative therapies that have been investigated is the exploration of biomedicine (botanical medicine) for possible filaricidal activities. The application of biochemicals to treat disease is among the oldest forms of healthcare known to humankind. Ancient Chinese characters and Egyptian papyrus hieroglyphs have documented the use of herbal medicine dating back to as early as 3000 B.C. [5]. In fact, herbal remedies had been in use by all cultures throughout the human history.

In recent years, it is not uncommon to find literature reported on the use of biochemical extracts against lymphatic filariasis [6-11]. Biological extracts such as those from Azadirachta indica [12], Polyalthia suaveolens [13], Andrographis paniculata [14], Bauhinia racemosa [15], and Haliclona oculata [16] were reported to have a bioactivity on either the filarial parasites or thier vectors. These extracts were believed to exert their bioefficacy through immunomodulatory elicitation of Th1/Th2 response, either by single (Th1, Th2) or mixed adjuvant activity. This paper presents a detailed review on the recent literature that reported the efficacy of direct filaricidal biomedicine or those employed as vector control agents. In addition, methods used for biochemical extraction, screening procedures, biochemical structure of the bioactive compounds and attempts made by researchers to evaluate the efficacy of the bio-chemical extract were also discussed.

\section{Biomedicinal Agents Used against Filarial Parasites}

2.1. Azadirachta indica (Family: Meliaceae). Popularly called "neem tree," the plant is a large evergreen tree with its height reaching up to $50 \mathrm{ft}$. [17]. It is widely distributed within the hot tropical regions especially in India and West Africa [18]. The leaves and bark of this tree have a bitter taste of triterpenoid bio-chemical component described as azadirachtin (Figure 2(a)) [19]. Almost every part of this tree is reported to be used in complementary medicine for the cure of different ailments such as antimicrobial [20], anti-inflammatory [21], anticancer [22], antimalarial [23], antiulcerogenic [24], and antifilarial [17] activities. Al-Rofaai et al. [12] reported the effect of $A$. indica leaf extract against the helminth Teladorsagia circumcincta (Table 1). Employing organic solvents extraction and aqueous fractionation methods, they found that the first stage larvae $\left(\mathrm{L}_{1}\right)$ were shown to be more sensitive having the lowest $\mathrm{LC}_{50}$ at $7.15 \mathrm{mg} / \mathrm{mL}$ of the extract as compared to $24.91 \mathrm{mg} / \mathrm{mL}$ on infective stage 


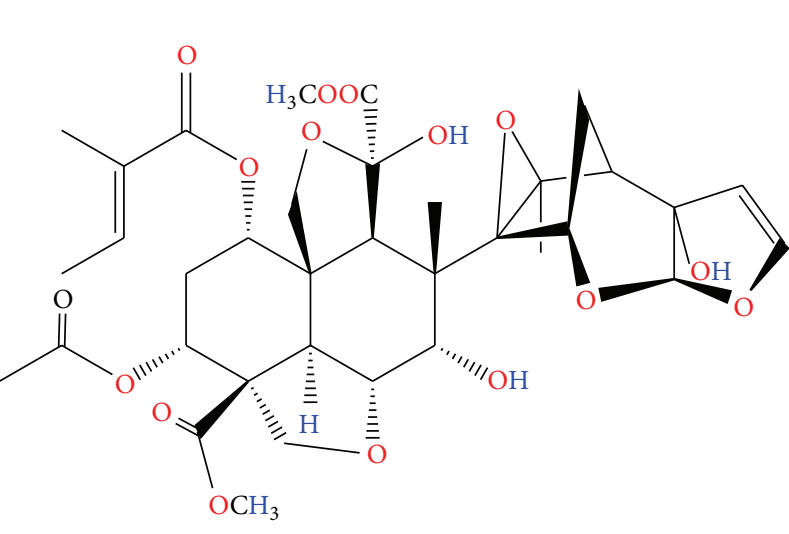

(a)

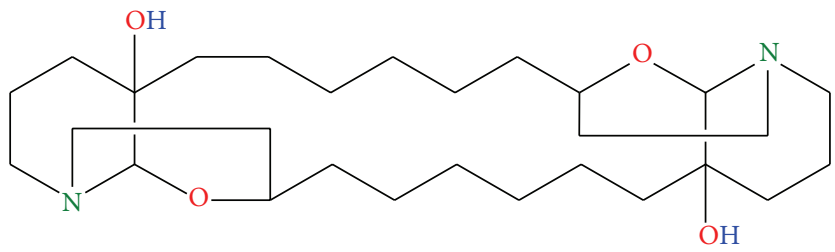

(c)

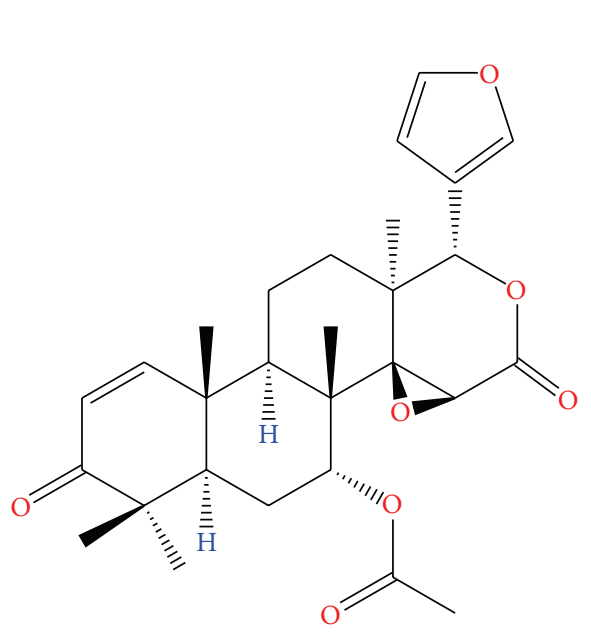

(e)

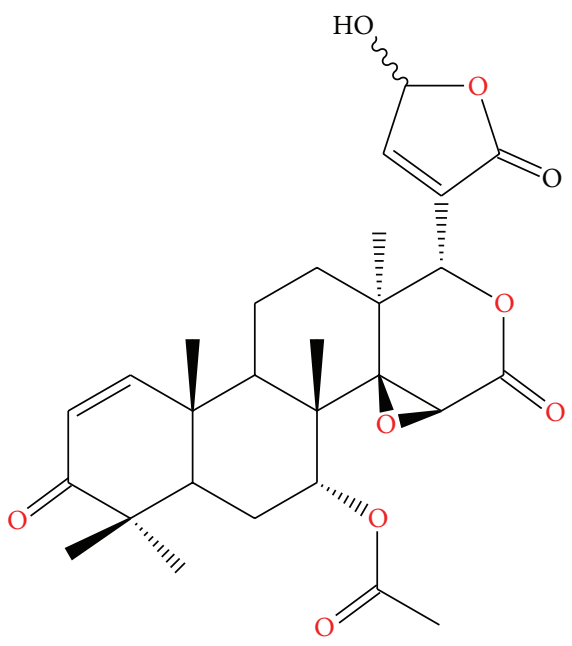

(f)

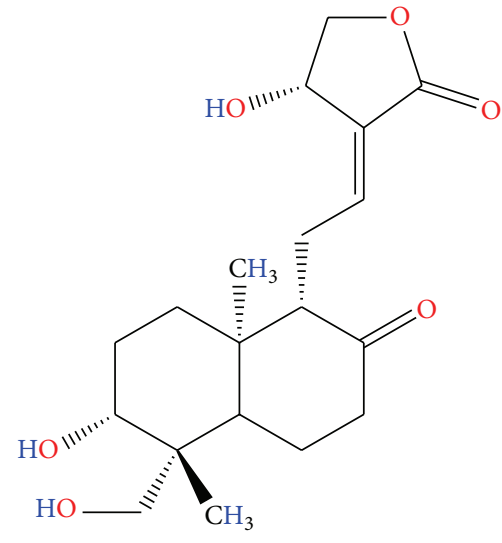

(b)<smiles>Cc1ccc(C(C)C)c(O)c1</smiles>

(d)<smiles>COc1cc(/C=C/C(=O)O)ccc1O</smiles>

(g)

Figure 2: Chemical structure of (a) azadirachtin [19], (b) andrographolide [25], (c) araguspongin C [26], (d) 2-isopropyl-5-methyl phenol [27], (e) gedunin [28], (f) photogedunin [28], and (g) ferulic acid [29].

larvae $\left(\mathrm{L}_{3}\right)$. Other workers employing distilled alcoholic and aqueous extracts of $A$. indica flowers showed that they have potential antifilarial activity against microfilariae of Setaria cervi [17]. The study also showed that the inhibition was concentration dependent, and both extracts were found to have almost similar lethal effect on the microfilariae of $S$. cervi, with $\mathrm{LC}_{50}$ being 15 and $18 \mathrm{ng} / \mathrm{mL}$, respectively [17].

2.2. Andrographis paniculata Linn. (Family: Acanthaceae). Andrographis paniculata (Kalmegh) is an annual herbaceous plant belonging to the family Acanthaceae, native to Southeast Asia especially China, India, and Sri Lanka. It has been traditionally used for centuries in Ayurvedic medicine. The herb has been revered for treating infectious diseases and highly regarded as having a preventative effect from many diseases, due to its powerful immune strengthening benefits [35]. Extensive research literature has revealed that A. paniculata has a broad range of pharmacological activities in different ailments such as being antianalgesic [36], antioxidant [37], antibiofilm [38], gastroprotective [39], wound healer [40], hepatoprotective [41], antifilarial [14], antimicrobial [42, 43], anticancer agent [44], antimalarial [45], and antitermitic [46]. It has been reported that the prophylactic effect of Andrographis was its ability to stop the catastrophic effect of the deadly flu virus of 1919 global epidemic from reaching India [47]. In fact, its bioactive diterpenoid andrographolide 
TABLE 1: Bioproduct with reported filaricidal activity.

\begin{tabular}{|c|c|c|c|c|c|c|}
\hline Name & Family & Part used & Extraction method & Filarial pathogen & Dosage & Reference \\
\hline \multirow[t]{2}{*}{ Azadirachta indica } & \multirow[t]{2}{*}{ Meliaceae } & Leaf & $\begin{array}{l}\text { Organic solvent } \\
\text { and water } \\
\text { fractionation }\end{array}$ & $\begin{array}{l}\text { Teladorsagia } \\
\text { circumcincta }\end{array}$ & $3.1-50 \mathrm{mg} / \mathrm{mL}$ & {$[12]$} \\
\hline & & Flower & $\begin{array}{c}\text { Distilled ethanol } \\
\text { Distilled water }\end{array}$ & Setaria cervi & $5-25 \mathrm{ng} / \mathrm{mL}$ & {$[17]$} \\
\hline \multirow{2}{*}{$\begin{array}{l}\text { Andrographis } \\
\text { paniculata }\end{array}$} & \multirow[t]{2}{*}{ Acanthaceae } & Leaf & Water decoction & $\begin{array}{l}\text { Dipetalonema } \\
\text { reconditum }\end{array}$ & $0.06 \mathrm{~mL} / \mathrm{Kg}$ & {$[30]$} \\
\hline & & Leaf & Aqueous extract & B. malayi & $0.5-10 \mathrm{mg} / \mathrm{mL}$ & {$[31]$} \\
\hline Heliclona oculata & Chalinidae & Sponges & $\begin{array}{c}\text { Methanol extract } \\
\text { solvents } \\
\text { fractionation }\end{array}$ & B. malayi & $100 \mathrm{mg} / \mathrm{Kg}$ & {$[16]$} \\
\hline Haliclona exigua & Chalinidae & Sponges & $\begin{array}{l}\text { methanolic extract } \\
\text { and butanol } \\
\text { fraction }\end{array}$ & B. malayi & $15.6-31.2 \mu \mathrm{m} / \mathrm{mL}$ & {$[26]$} \\
\hline $\begin{array}{l}\text { Trachyspermum } \\
\text { ammi L. }\end{array}$ & Apiaceae & Fruits & Methanolic extract & $\begin{array}{l}\text { Setaria digitata } \\
\text { B. malayi }\end{array}$ & $0.01-0.5 \mathrm{mg} / \mathrm{mL}$ & {$[27]$} \\
\hline Ricinus communis & Euphorbiaceae & Seed & $\begin{array}{c}\text { Methanolic extract } \\
\text { ethanol } \\
\text { fractionation }\end{array}$ & $\begin{array}{l}\text { B. malayi } \\
\text { S. digitata }\end{array}$ & $\begin{array}{c}10-100 \mu \mathrm{g} / \mathrm{mL} \\
1 \mathrm{mg} / \mathrm{mL}\end{array}$ & $\begin{array}{l}{[32]} \\
{[33]}\end{array}$ \\
\hline Morinda citrifolia & Rubiaceae & Fruits & Aqueous extract & W. bancrofti & $\begin{array}{c}0.02-0.04 \\
\text { noni : media }\end{array}$ & {$[34]$} \\
\hline $\begin{array}{l}\text { Xylocarpus } \\
\text { granatum }\end{array}$ & Meliaceae & Leaf & $\begin{array}{l}\text { Ethanolic extract } \\
\text { Aqueous extract }\end{array}$ & $\begin{array}{l}\text { B. malayi } \\
\text { B. pahangi }\end{array}$ & $\begin{array}{c}100 \mathrm{mg} / \mathrm{kg} \\
0.5-10 \mathrm{mg} / \mathrm{mL}\end{array}$ & $\begin{array}{l}{[28]} \\
{[31]}\end{array}$ \\
\hline Hibiscus sabdariffa & Malvaceae & Leaf & Ethanolic extract & B. malayi & $500 \mathrm{mg}-1 \mathrm{~g} / \mathrm{mL}$ & {$[8]$} \\
\hline
\end{tabular}

(Figure 2(b)) and its analogs were reported to block the MCF7 breast cancer cells cycle at the G0-G1 phase [25].

Kumarappan et al. [48] studied the antifilarial activity of alcoholic extract of $A$. paniculata. Another study reported that aqueous extract of the leaves showed microfilaricidal activity on Dipetalonema reconditum within $40 \mathrm{~min}$ (Table 1), both in vitro and in vivo [30]. Administration of the extract $(0.06 \mathrm{~mL} / \mathrm{Kg}$ body weight $)$ reduced the number of the microfilariae in infected dogs by more than 85\% [30]. Earlier, Zaridah et al. [31] reported the filaricidal activity of $A$. paniculata aqueous leaf extract against B. malayi. The authors analyzed the antifilarial activity of the extract using relative movability (RM) value of the adult worm over a period of $24 \mathrm{hr}$. The use of 5 or $10 \mathrm{mg} / \mathrm{mL}$ of the extract resulted in $0 \%$ of RM value signifying total death of the parasite. Lowering the concentration of extract to $1 \mathrm{mg} / \mathrm{mL}$, however, failed to produce similar effect (mean RM value was 35\%).

\subsection{Haliclona sp. (Family: Chalinidae). Haliclona oculata} does not belong to plant kingdom; it is a marine demospone of family Chalinidae in the animal kingdom. It is known to possess a variety of bioactivities against many diseases such as cancer [49], neurodegeneration [50], type 2 diabetes [51], and fungal and microbial infections $[52,53]$. The biological activity of these sponges is said to be due to the presence of novel sterols, metabolites including steroids, terpenoids, alkaloids, cyclic peptides, and unsaturated fatty acids [16]. Gupta et al. [16] reported the antifilarial activity of $H$. oculata against experimental lymphatic filaria B. malayi. Employing methanolic extract, chloroform fraction of the methanolic extract, and a fraction from the chromatographic eluent, at $100 \mathrm{mg} / \mathrm{kg}$ for five consecutive days by subcutaneous route, demonstrated significant macrofilaricidal efficacy of $51.3 \%$, $64 \%$, and $70.7 \%$, respectively. In all the samples, about $45-$ $50 \%$ macrofilaricidal activity with moderate embryostatic effect was observed. Further analyses on the chromatographic fraction revealed that it contained a mixture of four alkaloids, namely, mimosamycin, xestospongin $\mathrm{C}$, xestospongin $\mathrm{D}$, and araguspongin $\mathrm{C}$ together with few minor compounds [16]. Work done by Lakshmi et al. [26] on antifilarial activity of another species, $H$. exigua against lymphatic $B$. malayi in vitro and in vivo study, showed that $31.25 \mu \mathrm{g} / \mathrm{mL}$ concentrations of the crude methanolic extract and butanol soluble fraction were able to kill the adult worm, whereas the chloroform extract was found to be effective at lower concentration $(15.6 \mu \mathrm{g} / \mathrm{mL})$. According to the authors, such finding could be attributed to the single bioactive molecule "araguspongin C” (Figure 2(c)).

2.4. Trachyspermum ammi (Family: Apiaceae). Trachyspermum ammi (Ajwain) is a native of Egypt and is cultivated in Iraq, Iran, Afghanistan, Pakistan, and India [54]. It has been reported to possess various pharmacological activities like being anti-fungal, antioxidant, antimicrobial, antinociceptive, cytotoxic, hypolipidemic, anti-hypertensive, antispasmodic, bronchodilating, anti-lithiasis agent, diuretic, abortifacient, antitussive, nematicidal, anti-helmintic, and antifilarial [54]. Studies on its bio-chemical composition and characterization revealed the presence of various bio-chemical constituents, mainly carbohydrates, glycosides, 
saponins, phenolic compounds, volatile oil (thymol, $\gamma$ terpinene, para-cymene, and $\alpha$ - and $\beta$-pinene), protein, fat, fiber, and mineral matter containing calcium, phosphorous, iron, and nicotinic acid [54]. Mathew et al. [27] studied the effect of methanolic extract of $T$. ammi fruits against adult bovine filarial Setaria digitata worms at a concentration of $0.01-0.5 \mathrm{mg} / \mathrm{mL}$ for a period of $24-48 \mathrm{hr}$ (Table 1) and found that both the crude extract and the active fraction showed significant activity against the adult $S$. digitata by both worm motility and MTT (3-(4,5-dimethylthiazol-2yl)-2,5-diphenyltetrazolium bromide) reduction assays. They also isolated a compound and characterized it as phenolic monoterpene described as 2-isopropyl-5-methyl phenol (Figure 2(d)). When tested in vivo for antifilarial activity against the human filarial worm B. malayi in Mastomys coucha, it presented a macrofilaricidal activity where female worm sterility was detected.

2.5. Ricinus communis (Family: Euphorbiaceae). R. communis (castor oil plant) is commonly found in both the tropical and temperate climates of the world. The seed extract was reported to have efficacy in the treatment of warts, cold tumours, indurations of the mammary glands, corns, and moles, as well as being widely used as a human laxativecathartic agent [32]. Ramanathan and Shanmugapriya [32] observed the filaricidal effect of organic solvent extract of R. communis seed against filarial parasite B. malayi using different dosages $(10,50$, and $100 \mu \mathrm{g} / \mathrm{mL}$ of the extract) for the period of 24 hours. Their findings indicated dosedependent filaricidal activity (40-90\%). Nisha et al. [33] reported that treatment with ethanol fraction $(1 \mathrm{mg} / \mathrm{mL})$ of $R$. communis seed extract caused a complete suppression of S. digitata microfilarial growth within $1 \mathrm{hr}$ and $40 \mathrm{~min}$ (Table 1). Based on worm motility and MTT reduction assay, the authors found the seed extract to cause about $72.39 \%$ growth inhibition within $4 \mathrm{hr}$ of exposure [33].

2.6. Morinda citrifolia L. (Family: Rubiaceae). M. citrifolia (noni) is plant that could be found in a wide variety of habitats including volcanic terrains, lava-strewn coasts, and clearings or limestone outcrops. It can grow up to $9 \mathrm{~m}(30 \mathrm{ft})$ tall due to its tolerance to adverse agricultural conditions such as saline soils, drought conditions, and secondary soils. It has large, simple, dark green, shiny, and deeply veined leaves. The medicinal applications of this plant span over all kinds of ailments involving both modern and complementary medicines. Satapathy [34] reported the filaricidal activity of noni against $W$. bancrofti in an in vitro study. The study showed that adding noni fruit extract to culture media containing $W$. bancrofti microfilariae at a concentration of 2000 microfilaria per $\mathrm{mL}$ (Table 1) killed the parasite within 20 hours as compared to the control group without adding the extract, which survived for up to 60 hours [34].

2.7. Xylocarpus granatum (Family: Meliaceae). Xylocarpus granatum (nyireh bunga) is a mangrove swamp species with reported medicinal importance [31]. Misra et al. [28] found an in vivo filaricidal activity of $X$. granatum extract against B. malayi (both adult worm and microfilaria). On testing the crude aqueous ethanolic extract in vitro, they observed $\mathrm{IC}_{50}$ of 15.46 and $13.17 \mu \mathrm{g} / \mathrm{mL}$ in both adult worm and microfilariae, respectively. On the other hand, study on the ethyl acetate-soluble fraction revealed the antifilarial activity to be moderate ( $\mathrm{IC}_{50}$ of 8.5 and $6.9 \mu \mathrm{g} / \mathrm{mL}$ ) in both adult and microfilariae, respectively. They further found that on testing the extract's efficacy in vivo by administering it to Mastomys orally at $50 \mathrm{mg} / \mathrm{Kg}$, it showed adulticidal (52.8\%) and embryostatic (62.7\%) effects against B. malayi. Isolation of the bioactive biochemical components of this plant revealed eight pure molecules with two of these compounds, namely, gedunin (Figure 2(e)) and photogedunin (Figure $2(\mathrm{f})$ ), at $100 \mathrm{mg} / \mathrm{kg}$ by subcutaneous route revealing excellent adulticidal efficacy resulting in the death of about $80 \%$ B. malayi [28]. Previously, this species has been reported to have filaricidal activity against $B$. pahangi [55]. Filaricidal activity of $X$. granatum was further evaluated somewhere else.

2.8. Hibiscus sp. (Family: Malvaceae). H. sabdariffa (roselle) is a native of tropics, used for the production of fiber and infusions that are normally used as beverages. It is a woody shrub of annual to perennial seasoning. It is reported to have variant medicinal efficacy, especially on hypertensive patients [56]. The plant is said to be rich in anthocyanins, as well as dihydroxybenzoic acid. Daphniphylline forms the major pigment, while the dried calyces contain the flavonoids gossypetin, hibiscetine, and sabdaretine. In addition, small amounts of delphinidin-3monoglucoside, cyanidin-3-monoglucoside, and delphinidin were also present [56]. Moreover, the seeds were reported to be a good source of lipid-soluble antioxidants, particularly gamma-tocopherol [57]. Recently, Saxena et al. [8] reported for the first time the filaricidal activity of ethanolic extract of $H$. sabdariffa leafs against $B$. malayi (Table 1 ). The efficacy of the plant extract filaricidal activity was assessed using both the in vivo and in vitro motility and MTT reduction assays on the microfilariae (mf) and adult worms. The authors found that administering the leaf extract at $500 \mathrm{mg} / \mathrm{mL}$ for 5 days incurred about 30\% macrofilaricidal efficacy and $42 \%$ sterilization of female worms in Meriones unguiculatus. On the other hand, feeding $M$. coucha with the extract $(1 \mathrm{~g} / \mathrm{kg}$ for 5 days) exerted $57.0 \%$ macrofilaricidal activity with $64 \%$ sterilizing effect on female worms [8]. In similar studies, the crude methanolic extract of $H$. mutabilis (confederate rose) and the isolated bioactive molecule "ferulic acid" were tested against bovine S. cervi [29]. The authors reported that both the extract and the bioactive molecule "ferulic acid" (Figure 2(g)) showed significant microfilaricidal as well as macrofilaricidal activities against S. cervi. Using $500 \mu \mathrm{g} / \mathrm{mL}$ of the aqueous fraction of ethyl acetate extract, the authors reported about 50\% microfilarial motility inhibition within 24 hours and more than $80 \%$ within 48 hours, while adult worms motility inhibition was observed to be about $40 \%$ and $70 \%$ within 24 and 48 hours, respectively. Test on the bioactive compound ferulic acid was shown to be more effective. At a concentration of $400 \mu \mathrm{g} / \mathrm{mL}$, it caused $100 \%$ 
and $90 \%$ motility inhibition in both micro- and macrofilariae after 48 hours, respectively [29].

2.9. Cardiospermum halicacabum (Family: Sapindaceae). Cardiospermum halicacabum (love in a puff) is a climbing plant widely distributed in tropical and subtropical regions of Africa and Asia [58]. This plant has been reported to have bioactivity, such as being homoeopathic [58], having anti-diarrheal efficacy [59], and being antimicrobial [60, 61]. Khunkitti et al. [62] previously reported the in vitro filaricidal activity of ethanolic and aqueous extracts of this plant against B. pahangi. The researchers found activity on the adult worms and the amount of microfilariae released by female worms was concentration and time dependent. For example, using $500 \mu \mathrm{g} / \mathrm{mL}$ (Table 1), the authors observed that the aqueous extract significantly reduces motility of adult females after $24 \mathrm{~h}$ of exposure, the release of microfilariae from female worms on day 2 , and the motility of the adult males after 3 days. However, the aqueous extract at this concentration $(500 \mu \mathrm{g} / \mathrm{mL})$ did not affect the motility of microfilariae, with the exception of those in higher concentration extracts. In contrast, $500 \mu \mathrm{g} / \mathrm{mL}$ of the ethanol extract was found to rapidly reduce the motility of microfilariae on day 2 . Furthermore, higher concentrations of ethanol extracts $(2 \mathrm{mg} / \mathrm{mL})$ inhibit both the motility of adult worms and the release of microfilariae from females [62].

2.10. Excoecaria agallocha L. (Family: Euphorbiaceae). Excoecaria agallocha is a small tree species that inhabits the mangrove swamps of Southeast Asia and that can grow up to $15 \mathrm{~m}$ height. The tree has a well-developed chemical defense mechanism composing of diterpenoids, triterpenoids, and flavonoids [63]. The extract of this tree is reported to possess depressant action on the central nervous system [64], antimicrobial efficacy [65], and anti-viral and anti-carcinogenic activities [64]. Patra et al. [66] reported the antifilarial activities of methanolic and aqueous extracts of E. agallocha leaf against $S$. digitata were dose dependent at concentrations of 10,50 , and $100 \mu \mathrm{g} / \mathrm{mL}$ for $24 \mathrm{hrs}$ at $37^{\circ} \mathrm{C}$ in $5 \% \mathrm{CO}_{2}$ incubation. The study showed reduction in percentage of motility by about 20,60 , and $83 \%$, respectively. Testing the radical scavenging activity of the extract, the authors found the aqueous extract to be effective in 2,2-diphenyl-1picrylhydrazyl (DPPH) radical scavenging activity, reducing power, and hydrogen peroxide scavenging activity, which increased with the increase in concentration of the extract. Based on their observations, the authors concluded that Excoecaria agallocha can be a potential source of bioactive chemicals that can be used not only for meeting the oxidative stress generated during chronic manifestation of lymphatic filariasis in human beings but also for blocking embryogenesis in filarial parasites, which in turn can potentially affect their transmission and survival in host communities [66].

2.11. Alnus nepalensis (Family: Betulaceae). Alnus nepalensis (Nepalese Alder) is widely found in the subtropical highland of Himalaya. It is a fast growing deciduous tree that reaches up to $30 \mathrm{~m}$ in height, and it can grow on different kinds of soils especially in wet areas. The leaves are naturally shallow with dimension of $7-16 \mathrm{~cm}$ long and $5-10 \mathrm{~cm}$ broadness. Occasionally, the tree is used for making boxes, in light construction, and as firewood by the local people. Furthermore, it is sometimes planted as erosion control on hillsides and for land recovery in shifting cultivation. Recently, the in vitro and in vivo filaricidal activities of four bioactive compounds isolated from $A$. nepalensis leaves against human lymphatic filariasis (B. malayi) have been investigated for the first time [11]. The researchers designated the isolated diarylheptanoid biochemicals as compounds $(\mathrm{a}-\mathrm{d})$, that is, (a) platyphyllenone, (b) alusenone, (c) hirustenone, and (d) hirsutanonol, as shown in Figure 3. The authors reported that compounds (a) and (c) showed better efficacy as indicated by about $60 \%$ mean inhibition in motility of adult worms (Figure 4). Comparing the mean percentage MTT inhibition with the control synthetic drug diethylcarbamazine (DEC) in Figure 4, the authors concluded that A. nepalensis extract especially compound (c) showed a promising antifilarial activity against both the macro- and microfilarial worms of B. malayi.

2.12. Bauhinia racemosa Lam. (Family: Fabaceae). Bauhinia racemosa (mountain ebony) is a small deciduous tree native to the tropics especially Southeast Asia. Almost each and every part of this tree has some medicinal values [67]. The stem bark of the tree has analgesic activity [68], antidiabetic activity [69], and anti-helmintic activity [70] and is used in the treatment of headache, fever, skin diseases, blood diseases, dysentery, and diarrhea [67]. An extract of the leaves has been reported to show anti-histaminic effect [71], antimicrobial efficacy [72], and hypolipidemic activity [73], while a decoction of the dried fruits has antiulcer activity [74]. The tree is demonstrated to have antioxidant and hepatoprotective effects [75]. Sashidhara et al. [15] recently reported the filaricidal activity of the galactolipids compounds isolated from ethanolic extract of B. racemosa leaves. Results were based on the fractions tested (Figure 5); the nbutanol fraction of the extract revealed promising adulticidal $\left(\mathrm{IC}_{50} 5.46 \mathrm{mg} / \mathrm{mL}\right)$ and microfilaricidal $\left(\mathrm{IC}_{50} 4.89 \mathrm{mg} / \mathrm{mL}\right)$ activity, with minimum inhibitory concentration (MIC) of $15.6 \mathrm{mg} / \mathrm{mL}$ [15]. Among the characterized isolated galactolipid is (2S)-1,2-di-O-linolenoyl-3-O-a-galactopyranosyl(1/6)-O-b-galactopyranosyl glycerol (Figure 6), which they found to have filaricidal efficacy that rivals the standard drug ivermectin $\left(\mathrm{IC}_{50} 1.61 \mathrm{mg} / \mathrm{mL}\right.$; MIC $7.8 \mathrm{mg} / \mathrm{mL}$ in adult and $\mathrm{IC}_{50} 3.62 \mathrm{mg} / \mathrm{mL}$; MIC $125 \mathrm{mg} / \mathrm{mL}$ in microfilariae) in terms of dose and efficacy [15].

2.13. Cocos nucifera (Arecaceae). The coconut palm is widely distributed within the tropical and subtropical regions, growing up to 30 meters tall, with pinnate leaves 4-6 meters long. The tree has versatile importance spanning from domestic, commercial to medicinal applications. The biochemical analysis of the endosperm revealed the presence of terpenoids, alkaloids, resins, glycosides, steroids, and flavonoids $[76,77]$. Medically, coconut is reported to have efficacy against prostatic hyperplasia [78], anti-helmintic activity 
<smiles>O=C(/C=C/CCc1ccc(O)cc1)CCc1ccc(O)cc1</smiles>

(a) Platyphyllenone<smiles>O=C(/C=C/CCc1ccc(O)c(O)c1)CCc1ccc(O)cc1</smiles>

(b) Alusenone<smiles>O=C(/C=C/CCc1ccc(O)c(O)c1)CCc1ccc(O)c(O)c1</smiles>

(c) Hirustenone<smiles>O=C(CCc1ccc(O)c(O)c1)CC(O)CCc1ccc(O)c(O)c1</smiles>

(d) Hirsutanonol

FIgURE 3: Chemical structure of bioactive biochemicals extracted from A. nepalensis [11].

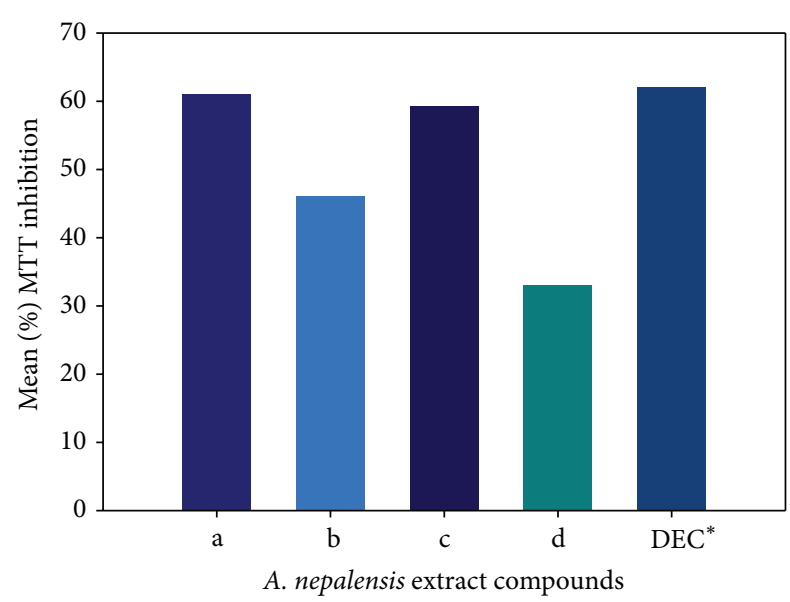

FIgURE 4: Effect of $A$. nepalensis extract on adult female worm motility inhibition, DEC* (diethylcarbamazine used as control).

[79], and antimicrobial and antiviral activities [80], vasorelaxant, antimalarial [81], and anti-hypertensive; activities, and inhibitory effect on oral microflora [82]. Furthermore, its bioactive compounds were found to have extended efficacy on agropest control [83]. Al-Adhroey et al. [81] studied the antimalarial efficacy of $C$. nucifera endocarp methanolic extract against Plasmodium berghei (NK65) infections in mice. The antimalarial activity was evaluated using different doses $(50,100,200$, and $400 \mathrm{mg} / \mathrm{kg})$ of the extract in reference to chloroquine $(20 \mathrm{mg} / \mathrm{kg})$ and pyrimethamine $(1.2 \mathrm{mg} / \mathrm{kg})$ drugs. Although, at 200 and $400 \mathrm{mg} / \mathrm{kg}$ doses, the extract revealed significant reduction of parasitaemia, it failed to increase the survival time of the infected mice.

\section{Medicinal Plants Used as Agents for Vector Control}

Among the methods used to manage filariasis is control its vectors, since filariasis is transmitted by mosquito vectors of the genera Aedes, Anopheles, Culex, and Mansonia. In this section, a review on the recent use of bio-chemical extracts in the control of these filarial vectors is presented.

Cocos nucifera (Arecaceae). Recently, Roopan et al. [84] employed the use of novel biosynthesis that reduced silver nitrate to biogenic silver nanoparticles in the presence 


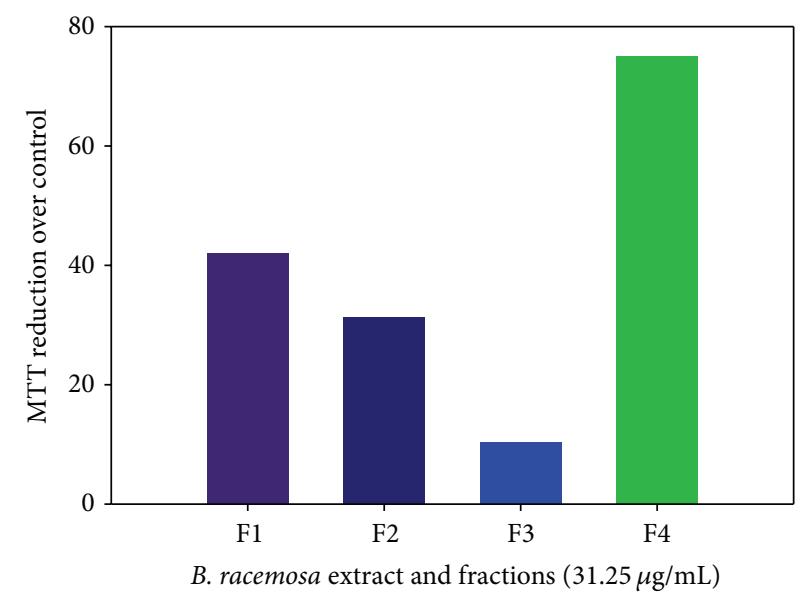

FIGURE 5: In vitro motility inhibition by MTT reduction assay as a function of $B$. racemosa extract and fractions exposure (F1: crude ethanolic extract; F2: $\mathrm{n}$-hexane fraction; F3: chloroform fraction; F4: n-butanol fraction).

C. nucifera extracts against A. stephensi and C. quinquefasciatus. The researchers reported about $100 \%$ and $92 \% 4$ th instar larval motility inhibition at $4 \mathrm{mg} / \mathrm{mL}$ dosage in both $A$ stephensi and C. quinquefasciatus after 72 hours, respectively.

Subarani et al. [85] observed the larvicidal activity of Vinca rosea (Apocynaceae) aqueous leaf extract biosynthesized silver nanoparticles also against A. stephensi Liston and C. quinquefasciatus. On exposure for 72 hours, the researchers found that the larvicidal activity showed maximum efficacy in synthesized silver nanoparticles against the fourth instar larvae of $A$. stephensi $\left(\mathrm{LC}_{50}=16.84 \mathrm{mg} / \mathrm{mL}\right)$ and against $C$. quinquefasciatus $\left(\mathrm{LC}_{50}=43.80 \mathrm{mg} / \mathrm{mL}\right)$.

Kovendan et al. [86] recently reported the larvicidal effect of $M$. citrifolia leaf extract against three medically important mosquito vectors of Anopheles, Aedes, and Culex genera. After 24 hours of exposure, the authors found that the larvicidal activity was concentration and extraction-solvent dependent (Figure 7).

Govindarajan et al. [87] reported the larvicidal and ovicidal activity of Cassia fistula Linn. (Fabaceae) methanolic leaf extract against C. quinquefasciatus and A. stephensi. The researchers found the activity of the extract $(10-50 \mathrm{mg} / \mathrm{L})$ was concentration dependent. At $40 \mathrm{mg} / \mathrm{L}$ the percent mortality was 89.33 and 100 in both Culex and Anopheles, respectively, with $\mathrm{LC}_{50}$ values recorded as 17.97 and $20.57 \mathrm{mg} / \mathrm{L}$, respectively, signifying that the extract is more potent to Anopheles than to the Culex larvae. Their investigation on the ovicidal activity of the extract, based on percentage of hatchability, showed that it was inversely proportional to the concentration $(25-200 \mathrm{mg} / \mathrm{L})$ used. The authors also investigated the bioefficacy of C. fistula leaf extract on $A$. aegypti. They reported that the activity was concentration and extraction-solvent dependent. In methanol extract, exposure to $25 \mathrm{mg} / \mathrm{L}$ for 24 hours resulted in $98 \%$ larval mortality. The percentage of mortality was reduced up to about $31 \%$ when the concentration was brought down to $5 \mathrm{mg} / \mathrm{L}$. Exposure to $20 \mathrm{mg} / \mathrm{L}$ of methanol extract for 24 hours resulted in about
$85 \%$ larval mortality. By using the same concentration, only $55 \%$ and $41 \%$ larval mortality were observed when employing benzene and acetone extracts, respectively.

In contrast to the earlier study, Rajkumar and Jebanesan [88] reported $\mathrm{LC}_{50}$ value of $52.2 \mathrm{mg} / \mathrm{L}$ in $A$. stephensi using ethanolic leaf extract of Chinese Senna (Cassia obtusifolia Linn.; Fabaceae). As for ovicidal activity, the researchers used an extract concentration of $100-400 \mathrm{mg} / \mathrm{L}$, and they found the oviposition deterrent activity of the leaf extract to be concentration dependent. At extract concentration of $400 \mathrm{mg} / \mathrm{L}$, oviposition effective repellency of $92.5 \%$ was indicated while at 300,200 , and $100 \mathrm{mg} / \mathrm{L}$ the effective repellency of $87.2 \%$, $83.0 \%$, and $75.5 \%$ was observed, respectively.

Recently, the bioefficacy of Carica papaya (Caricaceae) leaf extracts against $A$. aegypti larvicidal and pupicidal properties was reported [89]. The authors found that the leaf extract showed both larvicidal and pupicidal types of efficacy after $24 \mathrm{~h}$ of exposure. In all the extracts tested, the methanolic extract has the highest larval and pupal mortality against the larvae and pupae with values of $\mathrm{LC}_{50}$ of 51.76 , 61.87, 74.07, 82.18, and $440.65 \mathrm{ppm}$ for 1st, $2 \mathrm{nd}$, $3 \mathrm{rd}$, and 4 th instar larvae and pupae, respectively.

The author also evaluated the larvicidal activity of Acalypha alnifolia Klein ex Willd. (Euphorbiaceae) leaf extract against A. stephensi, A. aegypti, and C. quinquefasciatus [90]. Exposing the larvae to extract of different solvents for 24 hours, methanol extract was shown to be the most bioactive (98.4\% larval mortality) while hexane extract was found to be the least bioactive as shown in Figure 8.

A combined bioefficacy of the fruit extracts of Solanum xanthocarpum and copepods of Mesocyclops thermocyclopoides was assessed for the control of A. aegypti, respectively [91]. The $S$. xanthocarpum fruit extract revealed significant larval mortality to $A$. aegypti 1st-4th instar larvae exposed to dosage of $100-300 \mathrm{ppm}$ (the highest $\mathrm{LC}_{50}=$ $253.18 \mathrm{ppm})$. The authors reported an increase in the percentage of copepod predatory efficiency in the extract treated sample $(8.7 \%)$ as compared to $6.5 \%$ in samples without the extract. This increase in predation efficiency was opined by the authors to possibly be due to the detrimental effects of the extract active principle compound (solanocarpine and solanocarpidine) on the mosquito larvae [91].

Lalrotluanga et al. [92] recently reported the larvicidal, adulticidal, and repellent activity of Hiptage benghalensis L. Kruz (Malpighiaceae) acetone root bark extracts against mosquitos of Anopheles, Culex, and Aedes genera. The extract was found to be effective as larvicide with low $\mathrm{LC}_{50}$ (11.15$16.78 \mathrm{ppm})$ and lethal time $\mathrm{LT}_{50}(1.25-4.84 \mathrm{~h}$ at 200 and $400 \mathrm{ppm})$. The lethal time was found to be concentration dependent.

Kovendan et al. [93] reported their work on the larvicidal efficacy of Sphaeranthus indicus, Cleistanthus collinus, and Murraya koenigii organic-solvent leaf extracts against the third instar larvae of $C$. quinquefasciatus. Using a dosage of 750 ppm, significant mortality of larvae was observed. $S$. indicus extracts showed mortality of $78.62 \%$ in chloroform, $100 \%$ in ethyl acetate, and $60.16 \%$ in hexane extracts within 72 hours. C. collinus extract, on the other hand, showed $100 \%$ mortality in chloroform and $78.09 \%$ in hexane. Exposure to 


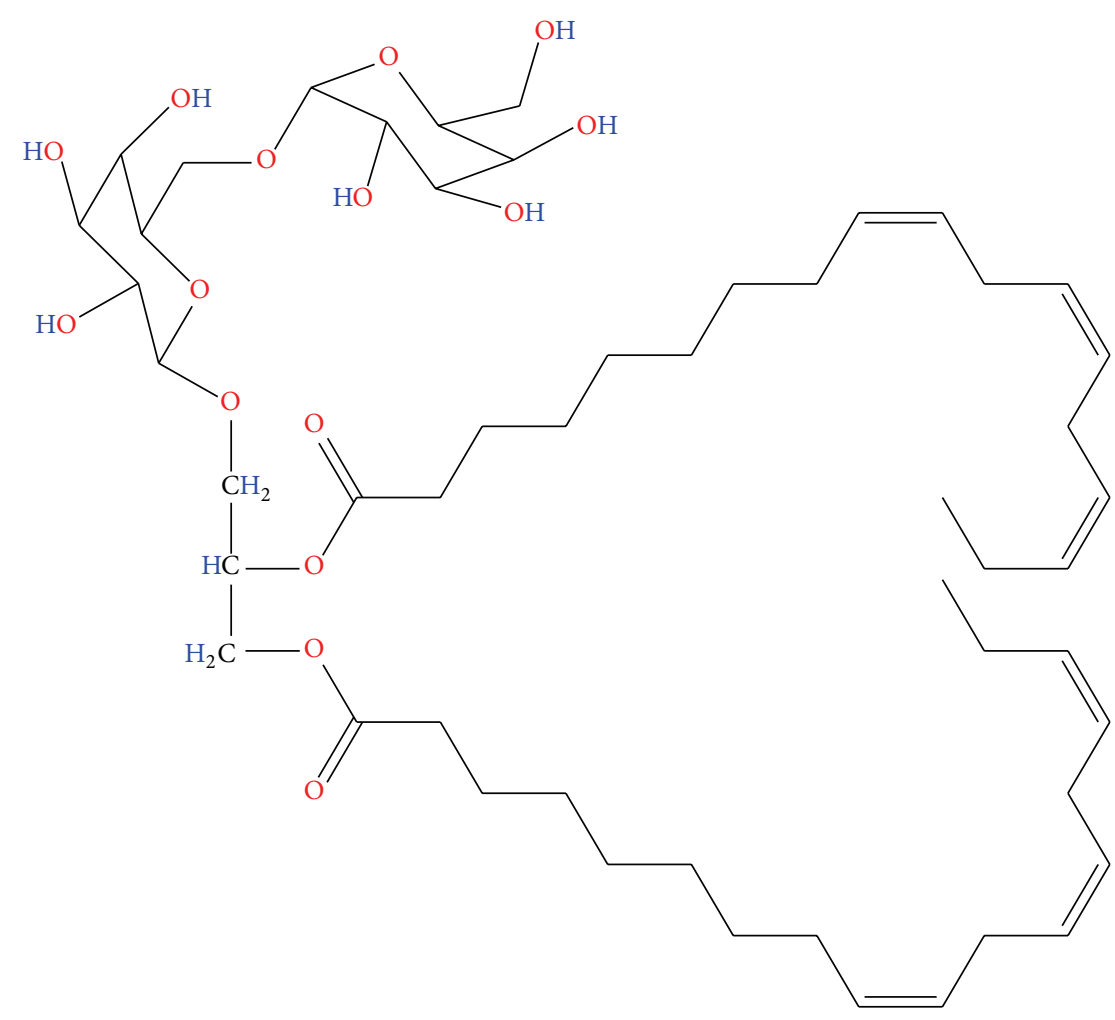

Figure 6: Chemical structure of the bioactive biochemical extracted from B. racemosa [15].

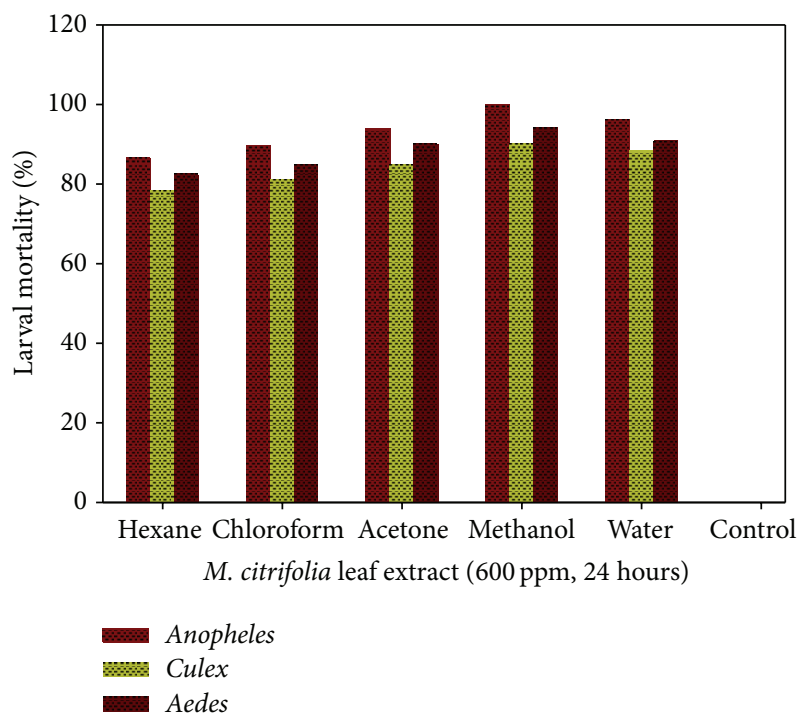

FIGURE 7: M. citrifolia solvent extract as a function of percent larval mortality.

M. koenigii extract for 72 hours showed mortality of $91.24 \%$ (ethyl acetate), 89.03\% (chloroform), and 86.35\% (hexane), respectively [93].

Indigofera suffruticosa Mill. (Fabaceae) is a plant found in tropical and subtropical areas and well adapted to growth in semiarid regions and low fertile soil. The plant has been known for its medicinal efficacy against bacterial and fungal

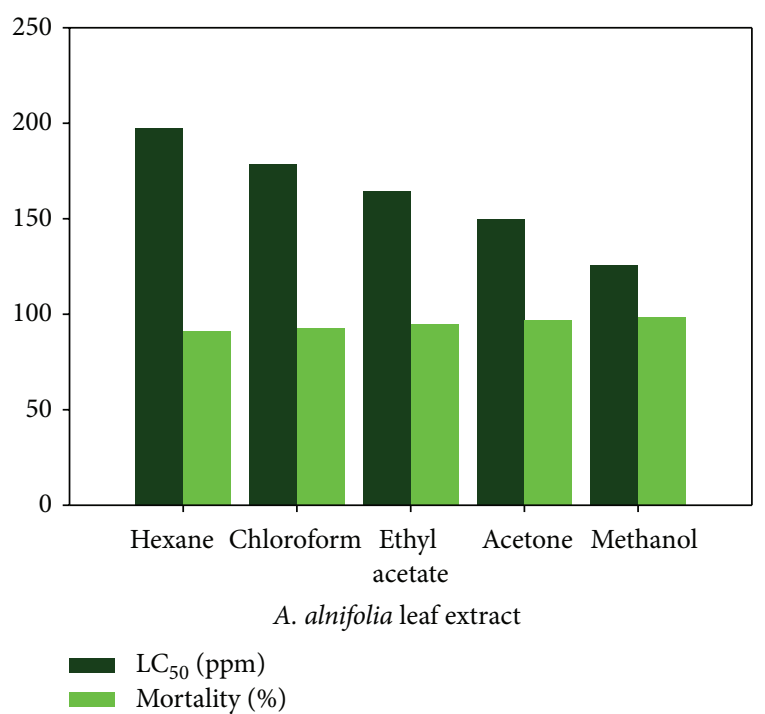

FIGURE 8: Influence of extraction solvent on larval percent mortality and $\mathrm{LC}_{50}$ during exposure to $A$. alnifolia extract.

infections [94]. Vieira et al. [94] reported their study on the oviposition and embryotoxicity of I. suffruticosa leaves extract against Aedes aegypti. The authors found the repellent activity to be concentration dependent. Exposing the larvae to concentration of $250 \mu \mathrm{g} / \mathrm{mL}$ for 72 hours showed $93.3 \%$ growth inhibition in L2 instar [94]. 


\section{Conclusion}

Ancient biomedicine described the use of plants in traditional system of medicine for the treatment of several human ailments, including filarial infections. This kind of complementary medicine provides an avenue for therapeutic treatment in a more benign approach, with plant materials that are mostly available and easily assessable. The present report is a survey of literature indicating the screenings of crude plant extracts, essential oils, and isolated active principles for in vitro and in vivo filaricidal activities to substantiate those folklore claims. It is worth mentioning that despite the fact that infection with $W$. bancrofti accounts for major incidence cases $(91 \%)$ of total lymphatic filariasis infections while $B$. malayi and B. timori are responsible for only $9 \%$ in South and Southeast Asia, literature on biomedicinal efficacy against bancroftian filariasis is highly scarce; specifically the research on that area seems to be neglected. Hence, we opined that, in future studies, more research on filaricidal biochemicals with efficacy on $W$. bancrofti is needed.

Furthermore, proper control of filarial vector can be achieved via careful design of extraction and administration processes such as use of efficient bio-chemical solvent extraction, preferably hydrophilic solvent, and logically controlled dosage.

\section{Conflict of Interests}

The authors have declared that no conflict of interests exists either financial or otherwise from any company or other entities.

\section{Acknowledgment}

This research was supported financially by The Ministry of Higher Education and University of Malaya Malaysia Grant nos. (FRGS FP011/2011 and PG085-2012B).

\section{References}

[1] M. J. Taylor, A. Hoerauf, and M. Bockarie, "Lymphatic filariasis and onchocerciasis," The Lancet, vol. 376, no. 9747, pp. 1175-1185, 2010.

[2] WHO, Lymphatic Filariasis, World Health Organisation, Geneva, Switzerland, 2012.

[3] M. J. Bockarie, E. M. Pedersen, G. B. White, and E. Michael, "Role of vector control in the global program to eliminate lymphatic filariasis," Annual Review of Entomology, vol. 54, pp. 469-487, 2009.

[4] V. Tangpu and A. K. Yadav, "In vitro filaricidal activity of some folklore medicinal plants of Manipur, India," in Parasites and Diseases, N. Gupta and D. K. Gupta, Eds., pp. 127-132, Neeraj, Bareilly, India, 2003.

[5] C. Andrew, The Encyclopedia of Medicinal Plants, DK Publishing, New York, NY, USA, 1996.

[6] N. Kumar, P. Misra, A. Dube, S. Bhattacharya, M. Dikshit, and S. Ranade, "Piper betle Linn. a maligned pan-asiatic plant with an array of pharmacological activities and prospects for drug discovery," Current Science, vol. 99, no. 7, pp. 922-932, 2010.
[7] J. K. Patra, N. K. Dhal, and H. N. Thatoi, "In vitro bioactivity and phytochemical screening of Suaeda maritima (Dumort): a mangrove associate from Bhitarkanika, India," Asian Pacific Journal of Tropical Medicine, vol. 4, no. 9, pp. 727-734, 2011.

[8] K. Saxena, V. Dube, V. Kushwaha et al., "Antifilarial efficacy of Hibiscus sabdariffa on lymphatic filarial parasite Brugia malayi," Medicinal Chemistry Research, vol. 20, no. 9, pp. 1594-1602, 2011.

[9] M. A. Zaman, Z. Iqbal, R. Z. Abbas et al., "In vitro and in vivo acaricidal activity of a herbal extract," Veterinary Parasitology, vol. 186, no. 3-4, pp. 431-436, 2012.

[10] L. M. Katiki, J. F. S. Ferreira, J. M. Gonzalez et al., "Anthelmintic effect of plant extracts containing condensed and hydrolyzable tannins on Caenorhabditis elegans, and their antioxidant capacity," Veterinary Parasitology, vol. 192, no. 1-3, pp. 218-227, 2013.

[11] D. Yadav, S. C. Singh, R. K. Verma et al., "Antifilarial diarylheptanoids from Alnus nepalensis leaves growing in high altitude areas of Uttarakhand, India," Biomedicine, vol. 20, pp. 124-132, 2013.

[12] A. Al-Rofaai, W. A. Rahman, S. F. Sulaiman, and Z. S. Yahaya, "In vitro activity of neem (Azadirachta indica) and cassava (Manihot esculenta) on three pre-parasitic stages of susceptible and resistant strains of Teladorsagia (Ostertagia) circumcincta," Veterinary Parasitology, vol. 188, no. 1-2, pp. 85-92, 2012.

[13] I. Ngantchou, B. Nyasse, C. Denier, C. Blonski, V. Hannaert, and B. Schneider, "Antitrypanosomal alkaloids from Polyalthia suaveolens (Annonaceae): their effects on three selected glycolytic enzymes of Trypanosoma brucei," Bioorganic \& Medicinal Chemistry Letters, vol. 20, no. 12, pp. 3495-3498, 2010.

[14] B. D. Sheeja, D. Sindhu, J. Ebanasar, and S. Jeeva, "Larvicidal activity of Andrographis paniculata (Burm.f) Nees against Culex quinquefasciatus Say (Insecta: Diptera-Culicidae), a filarial vector," Asian Pacific Journal of Tropical Disease, vol. 2, supplement 2, pp. S574-S578, 2012.

[15] K. V. Sashidhara, S. P. Singh, S. Misra, J. Gupta, and S. Misra-Bhattacharya, "Galactolipids from Bauhinia racemosa as a new class of antifilarial agents against human lymphatic filarial parasite, Brugia malayi," European Journal of Medicinal Chemistry, vol. 50, pp. 230-235, 2012.

[16] J. Gupta, S. Misra, S. K. Mishra et al., "Antifilarial activity of marine sponge Haliclona oculata against experimental Brugia malayi infection," Experimental Parasitology, vol. 130, no. 4, pp. 449-455, 2012.

[17] V. Mishra, N. Parveen, K. C. Singhal, and N. U. Khan, "Antifilarial activity of Azadirachta indica on cattle filarial parasite Setaria cervi," Fitoterapia, vol. 76, no. 1, pp. 54-61, 2005.

[18] H. L. Koh, T. K. Chua, and C. H. Tan, A Guide to Medicinal Plants: An Illustrated, Scientific and Medicinal Approach, World Scientific, 2009.

[19] G. E. Veitch, E. Beckmann, B. J. Burke, A. Boyer, S. L. Maslen, and S. V. Ley, "Synthesis of azadirachtin: a long but successful journey," Angewandte Chemie International Edition, vol. 46, no. 40, pp. 7629-7632, 2007.

[20] A. Tripathi, N. Chandrasekaran, A. M. Raichur, and A. Mukherjee, "Antibacterial applications of silver nanoparticles synthesized by aqueous extract of Azadirachta indica (Neem) leaves," Journal of Biomedical Nanotechnology, vol. 5, no. 1, pp. 93-98, 2009.

[21] M. Schumacher, C. Cerella, S. Reuter, M. Dicato, and M. Diederich, "Anti-inflammatory, pro-apoptotic, and antiproliferative effects of a methanolic neem (Azadirachta indica) 
leaf extract are mediated via modulation of the nuclear factor$\kappa \mathrm{B}$ pathway," Genes and Nutrition, vol. 6, no. 2, pp. 149-160, 2011.

[22] F. Othman, G. Motalleb, S. L. T. Peng, A. Rahmat, S. Fakurazi, and C. P. Pei, "Extract of Azadirachta indica (Neem) leaf induces apoptosis in $4 \mathrm{~T} 1$ breast cancer BALB/c mice," Cell Journal, vol. 13, no. 2, pp. 107-116, 2011.

[23] L. Lucantoni, R. S. Yerbanga, G. Lupidi, L. Pasqualini, F. Esposito, and A. Habluetzel, "Transmission blocking activity of a standardized neem (Azadirachta indica) seed extract on the rodent malaria parasite Plasmodium berghei in its vector Anopheles stephensi," Malaria Journal, vol. 9, no. 1, article 66, 2010.

[24] Q. Aziz, To Study the Anti-Ulcer Effect of Azadirachta indica Leaf Extract and Isolated Compound of Neemnimolicine ( $\mathrm{Nc}$ ) in Comparison with Ulcer Healing Drugs on Gastric Mucosa of Albino Rats, Baqai Medical University, Karachi, Pakistan, 2011.

[25] C. Satyanarayana, D. S. Deevi, R. Rajagopalan, N. Srinivas, and S. Rajagopal, "DRF 3188 a novel semi-synthetic analog of andrographolide: cellular response to MCF 7 breast cancer cells," BMC Cancer, vol. 4, article 26, 2004.

[26] V. Lakshmi, S. Srivastava, S. Kumar Mishra, S. Misra, M. Verma, and S. Misra-Bhattacharya, "In vitro and in vivo antifilarial potential of marine sponge, Haliclona exigua (Kirkpatrick), against human lymphatic filarial parasite Brugia malayi," Parasitology Research, vol. 105, no. 5, pp. 1295-1301, 2009.

[27] N. Mathew, S. Misra-Bhattacharya, V. Perumal, and K. Muthuswamy, "Antifilarial lead molecules isolated from Trachyspermum ammi," Molecules, vol. 13, no. 9, pp. 2156-2168, 2008.

[28] S. Misra, M. Verma, S. K. Mishra, S. Srivastava, V. Lakshmi, and S. Misra-Bhattacharya, "Gedunin and photogedunin of Xylocarpus granatum possess antifilarial activity against human lymphatic filarial parasite Brugia malayi in experimental rodent host," Parasitology Research, vol. 109, no. 5, pp. 1351-1360, 2011.

[29] P. Saini, P. Gayen, A. Nayak et al., "Effect of ferulic acid from Hibiscus mutabilis on filarial parasite Setaria cervi: molecular and biochemical approaches," Parasitology International, vol. 61, no. 4, pp. 520-531, 2012.

[30] A. Dutta and N. C. Sukul, "Filaricidal properties of a wild herb, Andrographis paniculata," Journal of Helminthology, vol. 56, no. 2, pp. 81-84, 1982.

[31] M. Z. Zaridah, S. Z. Idid, A. Wan Omar, and S. Khozirah, "In vitro antifilarial effects of three plant species against adult worms of subperiodic Brugia malayi," Journal of Ethnopharmacology, vol. 78, no. 1, pp. 79-84, 2001.

[32] T. Ramanathan and R. Shanmugapriya, "Antifilarial activity of seed extracts of Ricinus communis against Brugia malayi," Journal of Pharmacy Research, vol. 5, no. 3, pp. 1448-1450, 2012.

[33] M. Nisha, M. Kalyanasundaram, K. P. Paily, A. Abidha, P. Vanamail, and K. Balaraman, "In vitro screening of medicinal plant extracts for macrofilaricidal activity," Parasitology Research, vol. 100, no. 3, pp. 575-579, 2007.

[34] R. Satapathy, "Effect of Noni (Morinda citrifolia L.) on filarial worm infestation in vitro study," Noni Clinical Research Journal, vol. 1, pp. 34-36, 2007.

[35] C. V. Chandrasekaran, P. Thiyagarajan, K. Sundarajan et al., "Evaluation of the genotoxic potential and acute oral toxicity of standardized extract of Andrographis paniculata (KalmCold)," Food and Chemical Toxicology, vol. 47, no. 8, pp. 1892-1902, 2009.
[36] G. Shivaprakash, H. Gopalakrishna, D. S. Padbidri, S. Sadanand, S. S. Sekhar, and R. N. Shetty, "Evaluation of Andrographis paniculata leaves extract for analgesic activity," Journal of Pharmacy Research, vol. 4, pp. 3375-3377, 2011.

[37] S. W. Qader, M. A. Abdulla, L. S. Chua, N. Najim, M. M. Zain, and S. Hamdan, "Antioxidant, total phenolic content and cytotoxicity evaluation of selected Malaysian plants," Molecules, vol. 16, no. 4, pp. 3433-3443, 2011.

[38] K. Murugan, K. Selvanayaki, and S. Al-Sohaibani, "Antibiofilm activity of Andrographis paniculata against cystic fibrosis clinical isolate Pseudomonas aeruginosa," World Journal of Microbiology and Biotechnology, vol. 27, no. 7, pp. 1661-1668, 2011.

[39] S. Q. Wasman, A. A. Mahmood, L. S. Chua, M. A. Alshawsh, and S. Hamdan, "Antioxidant and gastroprotective activities of Andrographis paniculata (Hempedu Bumi) in Sprague Dawley rats," Indian Journal of Experimental Biology, vol. 49, no. 10, pp. 767-772, 2011.

[40] F. H. Al-Bayaty, M. A. Abdulla, M. I. A. Hassan, and H. M. Ali, "Effect of Andrographis paniculata leaf extract on wound healing in rats," Natural Product Research, vol. 26, no. 5, pp. 423429, 2012.

[41] W. W. Chao and B. F. Lin, "Hepatoprotective diterpenoids isolated from Andrographis paniculata," Chinese Medicine, vol. 3, pp. 136-143, 2012.

[42] R. Arunadevi, S. Sudhakar, and A. P. Lipton, "Assessment of antibacterial activity and detection of small molecules in different parts of Andrographis paniculata," Journal of Theoretical and Experimental Biology, vol. 6, article 192, 2010.

[43] P. K. Singha, S. Roy, and S. Dey, "Antimicrobial activity of Andrographis paniculata," Fitoterapia, vol. 74, no. 7-8, pp. 692694, 2003.

[44] R. Ajaya Kumar, K. Sridevi, N. Vijaya Kumar, S. Nanduri, and S. Rajagopal, "Anticancer and immunostimulatory compounds from Andrographis paniculata," Journal of Ethnopharmacology, vol. 92, no. 2-3, pp. 291-295, 2004.

[45] M. Govindarajan, "Evaluation of Andrographis paniculata Burm.f. (Family: Acanthaceae) extracts against Culex quinquefasciatus (Say.) and Aedes aegypti (Linn.) (Diptera: Culicidae)," Asian Pacific Journal of Tropical Medicine, vol. 4, no. 3, pp. 176181, 2011.

[46] G. Elango, A. Abdul Rahuman, C. Kamaraj et al., "Efficacy of medicinal plant extracts against Formosan subterranean termite, Coptotermes formosanus," Industrial Crops and Products, vol. 36, no. 1, pp. 524-530, 2012.

[47] I. Shipard, King of Bitters (Andrographis paniculata), 2009, http://herbsarespecial.com.au/isabells_blog/isabells-articles/ king-of-bitters.html.

[48] C. Kumarappan, S. Senthil, S. K. K. Sundari, and A. Jaswanth, "Anti-filarial activity of some valuable Indian medicinal plants," Asian Journal of Experimental Sciences, vol. 23, pp. 553-558, 2009.

[49] L. Coello, M. J. Martín, and F. Reyes, "1,5-diazacyclohenicosane, a new cytotoxic metabolite from the marine sponge Mycale sp," Marine Drugs, vol. 7, no. 3, pp. 445-450, 2009.

[50] K. V. Rao, M. S. Donia, J. Peng et al., "Manzamine B and E and ircinal A related alkaloids from an Indonesian Acanthostrongylophora sponge and their activity against infectious, tropical parasitic, and Alzheimer's diseases," Journal of Natural Products, vol. 69, no. 7, pp. 1034-1040, 2006.

[51] I. Orhan, B. Şener, M. Kaiser, R. Brun, and D. Tasdemir, "Inhibitory activity of marine sponge-derived natural products 
against parasitic protozoa," Marine Drugs, vol. 8, no. 1, pp. 47$58,2010$.

[52] A. Lipton, "Antifungal and cytotoxic activities of some marine sponges collected from the south east coast of India," Journal of Applied Pharmaceutical Science, vol. 2, pp. 52-55, 2012.

[53] I. Rajendran, K. Sobhana, G. Annie Selva Sonia, K. Chakraborty, K. Vijayan, and P. Vijayagopal, "Antibacterial and antifungal properties of southeast Indian coastal sponges," Journal of the Marine Biological Association of India, vol. 53, pp. 272-274, 2011.

[54] R. Bairwa, R. Sodha, and B. Rajawat, "Trachyspermum ammi," Pharmacognosy Reviews, vol. 6, article 56, 2012.

[55] W. Omar, A. J. Ibrahim, O. Sulaiman, and Y. Hashim, "Screening of local plants for antifilarial activity against adult worm and microfilaria of Brugia pahangi," Journal of Tropical Forest Products, vol. 3, pp. 216-219, 1997.

[56] B. H. Ali, N. Al Wabel, and G. Blunden, "Phytochemical, pharmacological and toxicological aspects of Hibiscus sabdariffa L.: a review," Phytotherapy Research, vol. 19, no. 5, pp. 369-375, 2005.

[57] R. Mohamed, J. Fernández, M. Pineda, and M. Aguilar, "Roselle (Hibiscus sabdariffa) seed oil is a rich source of $\gamma$-tocopherol," Journal of Food Science, vol. 72, no. 3, pp. S207-S211, 2007.

[58] EMEA, Committee for Veterinary Medicibnal Product Cardiospermum Halicacabum, The European Agency for the Evaluation of Medicinal Products, 1999, http://www.ema .europa.eu/ema/pages/includes/document/open_document .jsp?webContentId=WC500011402.

[59] N. V. Rao, K. C. Prakash, and S. M. S. Kumar, "Pharmacological investigation of Cardiospermum halicacabum (Linn) in different animal models of diarrhoea," Indian Journal of Pharmacology, vol. 38, no. 5, pp. 346-349, 2006.

[60] H. shareef, G. H. Rizwani, S. Mahmood, R. Khursheed, and H. Zahid, "In vitro antimicrobial and biochemiccal analysis of Cardiospermum halicacabum L.," Pakistan Journal of Botany, vol. 44, pp. 1677-1680, 2012.

[61] T. Deepan, V. Alekhya, P. Saravanakumar, and M. Dhanaraju, "Biochemical and anti-microbial studies on the leaves extracts of Cardiospermum halicacabum Linn," Advances in Biological Research, vol. 6, pp. 14-18, 2012.

[62] W. Khunkitti, Y. Fujimaki, and Y. Aoki, "In vitro antifilarial activity of extracts of the medicinal plant Cardiospermum halicacabum against Brugia pahangi," Journal of Helminthology, vol. 74, no. 3, pp. 241-246, 2000.

[63] J.-H. Zou, J. Dai, X. Chen, and J.-Q. Yuan, "Pentacyclic triterpenoids from leaves of Excoecaria agallocha," Chemical and Pharmaceutical Bulletin, vol. 54, no. 6, pp. 920-921, 2006.

[64] N. Subhan, M. A. Alam, F. Ahmed, I. J. Shahid, L. Nahar, and S. D. Sarker, "Bioactivity of Excoecaria agallocha," Brazilian Journal of Pharmacognosy, vol. 18, no. 4, pp. 521-526, 2008.

[65] V. Vadlapudi, V. Bobbarala, S. Penumajji, and K. C. Naidu, "Excoecaria agallocha L. antimicrobial properties against important pathogenic microorganisms," International Journal of PharmTech Research, vol. 1, no. 4, pp. 865-867, 2009.

[66] J. K. Patra, A. D. Mohapatra, S. K. Rath, N. K. Dhal, and H. Thatoi, "Screening of antioxidant and antifilarial activity of leaf extracts of Excoecaria agallocha L," International Journal of Integrative Biology, vol. 7, no. 1, pp. 9-15, 2009.

[67] P. P. Phalak, The Real Gold, http://giftingtrees.blogspot.com/2010/10/real-gold.html.

[68] V. Borikar, C. R. J. D. S. Rekhe, and P. Philip, "Study of Analgesic activity of Bauhinia racemosa iam in rats," Veterinary World, vol. 2, pp. 135-136, 2009.
[69] P. Kumar, S. Baraiya, S. Gaidhani, M. Gupta, and M. M. Wanjari, "Antidiabetic activity of stem bark of Bauhinia variegata in alloxan-induced hyperglycemic rats," Journal of Pharmacology \& Pharmacotherapeutics, vol. 3, no. 1, pp. 64-66, 2012.

[70] T. Kumar, A. Alexander, D. D. Ajazuddin, J. Khan, and M. Sharma, "Investigation of in vitro anthelmintic activity of Bauhinia racemosa Linn," Journal of Applied Pharmaceutical Science, vol. 1, pp. 73-75, 2011.

[71] S. A. Nirmal, R. B. Laware, R. A. Rathi, V. V. Dhasade, and B. S. Kuchekar, "Antihistaminic effect of Bauhinia racemosa leaves," Journal of Young Pharmacists, vol. 3, no. 2, pp. 129-131, 2011.

[72] G. Kumar, L. Karthik, and K. V. B. Rao, "Biochemical composition and in vitro antimicrobial activity of Bauhinia racemosa Lamk (Caesalpiniaceae)," International Journal of Pharmaceutical Sciences and Research, vol. 1, pp. 51-58, 2010.

[73] K. V. Sashidhara, S. P. Singh, A. Srivastava, and A. Puri, "Main extracts and hypolipidemic effects of the Bauhinia racemosaLam. leaf extract in HFD-fed hamsters," Natural Product Research, vol. 27, no. 12, pp. 1127-1131, 2013.

[74] V. Borikar, C. Jangde, P. Philip, and D. Rekhe, "Study of antiulcer activity of Bauhinia racemosa Lam in rats," Veterinary World, vol. 2, pp. 215-216, 2009.

[75] E. A. Adewusi and A. J. Afolayan, "A review of natural products with hepatoprotective activity," Journal of Medicinal Plant Research, vol. 4, no. 13, pp. 1318-1334, 2010.

[76] O. Obidoa, P. E. Joshua, and N. J. Eze, "Biochemical analysis of Cocos nucifera L," Pharmacy Research, vol. 3, pp. 280-286, 2010.

[77] G. Kanchana and J. P. Dyana, "Preliminary biochemical screening of Cocos nucifera L. flowers," International Journal of Current Pharmaceutical Research, vol. 4, pp. 62-63, 2012.

[78] M. L. Arruzazabala, V. Molina, R. Más et al., Journal of Pharmacy and Pharmacology, vol. 59, pp. 995-999, 2007.

[79] L. M. B. Oliveira, C. M. L. Bevilaqua, C. T. C. Costa et al., "Anthelmintic activity of Cocos nucifera L. against sheep gastrointestinal nematodes," Veterinary Parasitology, vol. 159, no. 1, pp. 55-59, 2009.

[80] D. Esquenazi, M. D. Wigg, M. M. F. S. Miranda et al., "Antimicrobial and antiviral activities of polyphenolics from Cocos nucifera Linn. (Palmae) husk fiber extract," Research in Microbiology, vol. 153, no. 10, pp. 647-652, 2002.

[81] A. H. Al-Adhroey, Z. M. Nor, H. M. Al-Mekhlafi, A. A. Amran, and R. Mahmud, "Evaluation of the use of Cocos nucifera as antimalarial remedy in Malaysian folk medicine," Journal of Ethnopharmacology, vol. 134, no. 3, pp. 988-991, 2011.

[82] R. Singla, "Review on the pharmacological properties of Cocos Nucifera endocarp," vol. 3, no. 5, Article ID WMC003413, 2012.

[83] P. U. Rani, T. Venkateshwaramma, and P. Devanand, "Bioactivities of Cocos nucifera L. (Arecales: Arecaceae) and Terminalia catappa L. (Myrtales: Combretaceae) leaf extracts as postharvest grain protectants against four major stored product pests," Journal of Pest Science, vol. 84, no. 2, pp. 235-247, 2011.

[84] S. M. Roopan, G. Madhumitha, A. A. Rahuman, C. Kamaraj, A. Bharathi, and T. Surendra, "Low-cost and eco-friendly bio-synthesis of silver nanoparticles using Cocos nucifera coir extract and its larvicidal activity," Industrial Crops and Products, vol. 43, pp. 631-635, 2013.

[85] S. Subarani, S. Sabhanayakam, and C. Kamaraj, "Studies on the impact of biosynthesized silver nanoparticles (AgNPs) in relation to malaria and filariasis vector control against Anopheles stephensi Liston and Culex quinquefasciatus Say (Diptera: Culicidae)," Parasitology Research, vol. 112, no. 2, pp. 487-499, 2012. 
[86] K. Kovendan, K. Murugan, S. P. Shanthakumar, S. Vincent, and J. S. Hwang, "Larvicidal activity of Morinda citrifolia L. (Noni) (Family: Rubiaceae) leaf extract against Anopheles stephensi, Culex quinquefasciatus, and Aedes aegypti," Parasitology Research, vol. 111, no. 4, pp. 1481-1490, 2012.

[87] M. Govindarajan, A. Jebanesan, and T. Pushpanathan, "Larvicidal and ovicidal activity of Cassia fistula Linn. leaf extract against filarial and malarial vector mosquitoes," Parasitology Research, vol. 102, no. 2, pp. 289-292, 2008.

[88] S. Rajkumar and A. Jebanesan, "Larvicidal and oviposition activity of Cassia obtusifolia Linn (Family: Leguminosae) leaf extract against malarial vector, Anopheles stephensi Liston (Diptera: Culicidae)," Parasitology Research, vol. 104, no. 2, pp. 337-340, 2009.

[89] K. Kovendan, K. Murugan, C. Panneerselvam et al., "Antimalarial activity of Carica papaya (Family: Caricaceae) leaf extract against Plasmodium falciparum," Asian Pacific Journal of Tropical Disease, vol. 2, supplement 1, pp. S306-S311, 2012.

[90] K. Kovendan, K. Murugan, and S. Vincent, "Evaluation of larvicidal activity of Acalypha alnifolia Klein ex Willd. (Euphorbiaceae) leaf extract against the malarial vector, Anopheles stephensi, dengue vector, Aedes aegypti and Bancroftian filariasis vector, Culex quinquefasciatus (Diptera: Culicidae)," Parasitology Research, vol. 110, no. 2, pp. 571-581, 2012.

[91] P. Mahesh Kumar, K. Murugan, K. Kovendan et al., "Mosquitocidal activity of Solanum xanthocarpum fruit extract and copepod Mesocyclops thermocyclopoides for the control of dengue vector Aedes aegypti," Parasitology Research, vol. 111, no. 2, pp. 609-618, 2012.

[92] L. Lalrotluanga, L. Ngente, S. K. Nachimuthu, and G. Guruswa$\mathrm{mi}$, "Insecticidal and repellent activity of Hiptage benghalensis L. Kruz (Malpighiaceae) against mosquito vectors," Parasitology Research, vol. 111, no. 3, pp. 1007-1017, 2012.

[93] K. Kovendan, S. Arivoli, R. Maheshwaran, K. Baskar, and S. Vincent, "Larvicidal efficacy of Sphaeranthus indicus, Cleistanthus collinus and Murraya koenigii leaf extracts against filarial vector, Culex quinquefasciatus Say (Diptera: Culicidae)," Parasitology Research, vol. 111, no. 3, pp. 1025-1035, 2012.

[94] J. R. C. Vieira, R. M. P. Leite, I. R. Lima, D. D. A. F. Navarro, E. M. Bianco, and S. P. Leite, "Oviposition and embryotoxicity of Indigofera suffruticosa on early development of Aedes aegypti (Diptera: Culicidae)," Evidence-Based Complementary and Alternative Medicine, vol. 2012, Article ID 741638, 5 pages, 2012. 


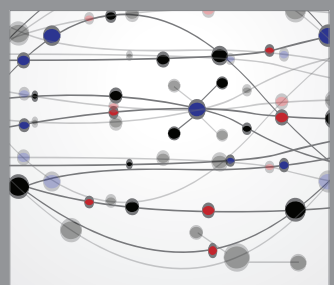

The Scientific World Journal
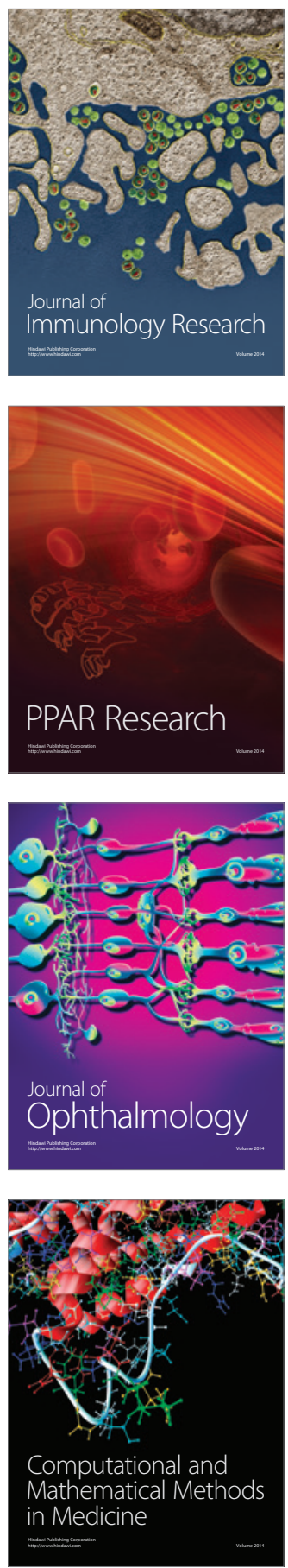

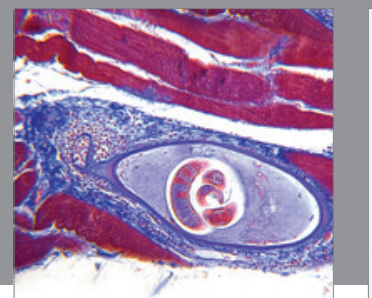

Gastroenterology

Research and Practice
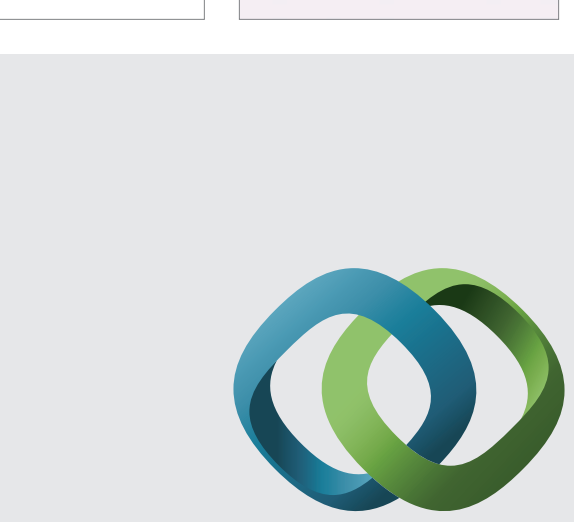

\section{Hindawi}

Submit your manuscripts at

http://www.hindawi.com
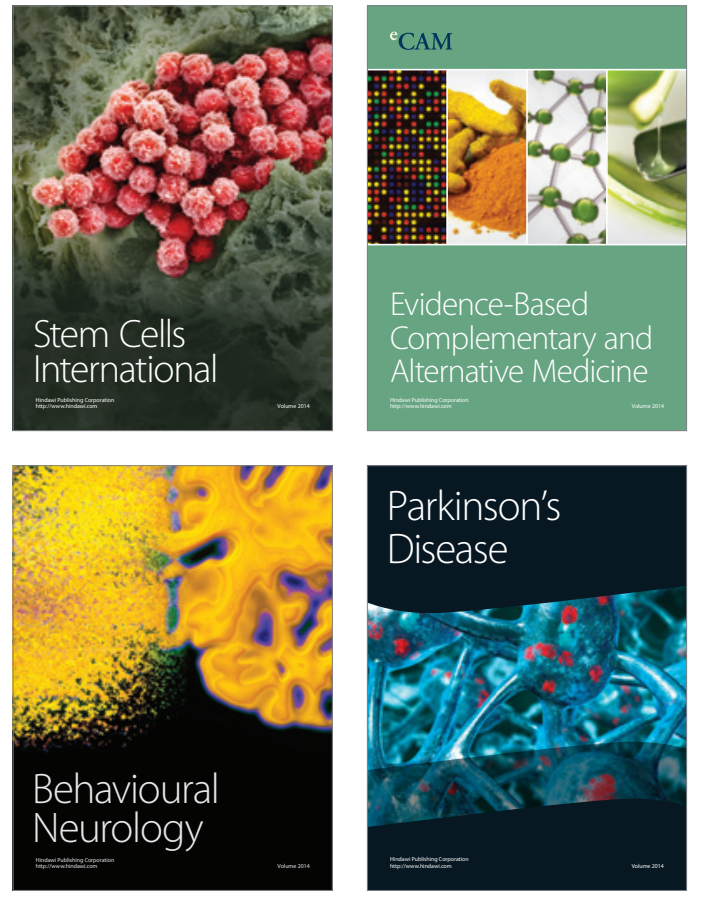
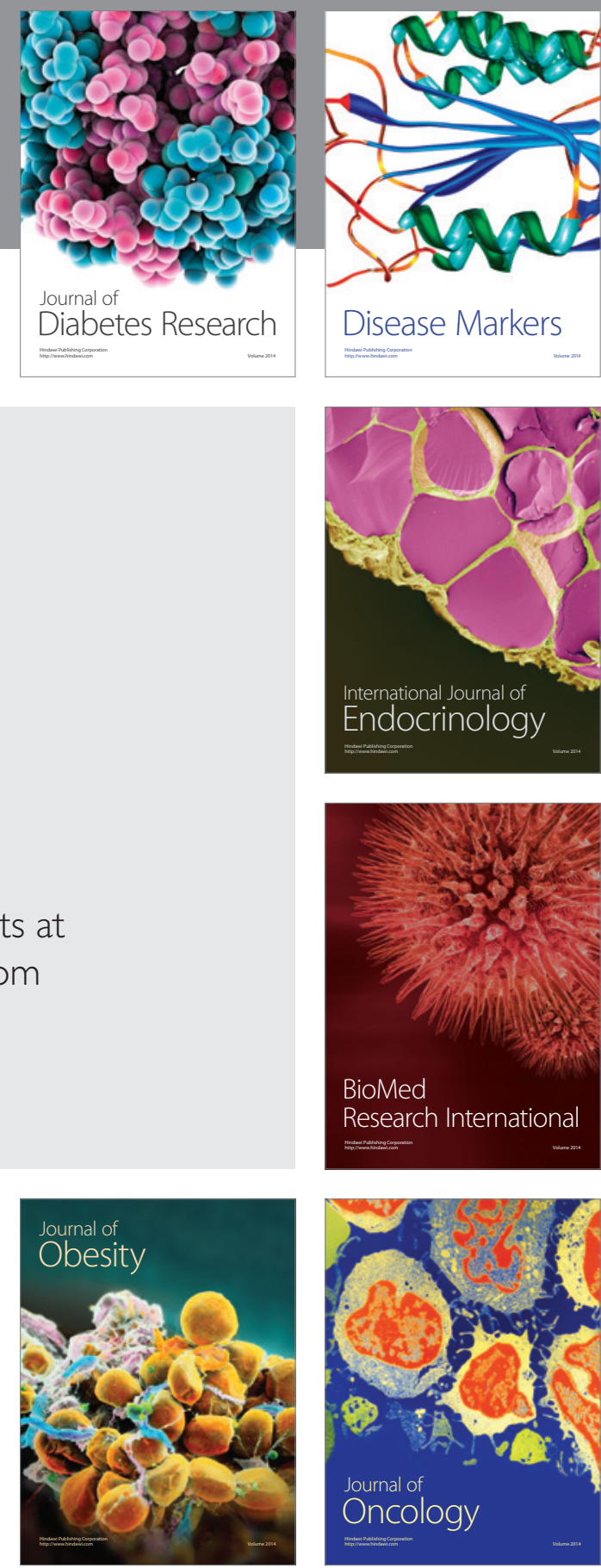

Disease Markers
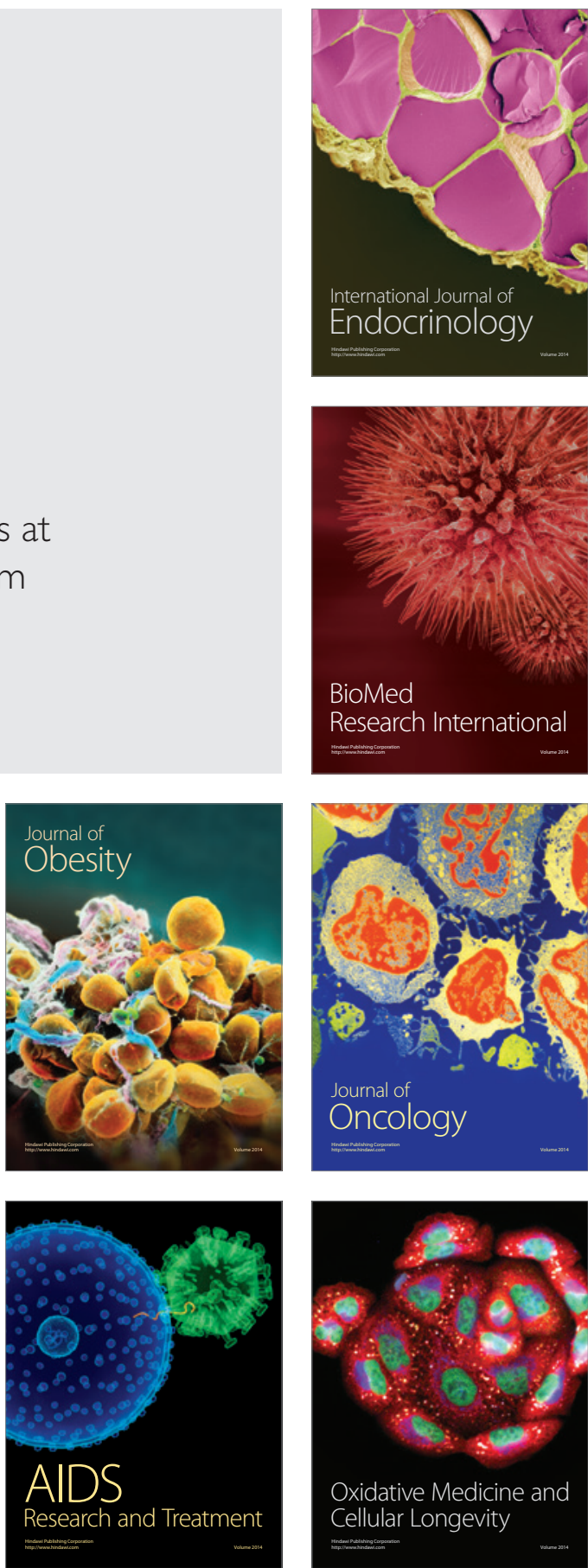